\title{
AicQoL2021BukitTinggi
}

https://www.amerabra.org; https://fspu.uitm.edu.my/cebs; https://www.emasemasresources.com/

AMER International Conference on Quality of Life

Colmar Tropicale, Bukit Tinggi, Malaysia, 17-18 Mar 2021

\section{New Norm for Traditional Food Business by SMEs Entrepreneurs: Case Study in Kota Kinabalu, Sabah}

\author{
Harifah Mohd Noor ${ }^{1}$, Ubong Imang ${ }^{1}$, Adilah Md Ramli², Rima Abdul Rahman ${ }^{3}$, Teuku Afrizal ${ }^{4}$ \\ ${ }^{1}$ Faculty of Social Sciences and Humanities (FSSK), University Malaysia Sabah, Malaysia, \\ ${ }^{2}$ Faculty of Food Science and Nutrition, University Malaysia Sabah, Malaysia, \\ ${ }^{3}$ Centre for Postgraduate Studies, University Malaysia Sabah, Malaysia \\ ${ }_{4}^{4}$ Fakultas IImu Sosial dan IImu Politik, Universitas Dipinegoro, Jawa Tengah, Indonesia
}

harifah@ums.edu.my, ubong@ums.edu.my, m_adilah@ums.edu.my, rimar7299@gmail.com,teukurian@lecturer.undip.ac.id Tel: +0198161163

\begin{abstract}
Traditional food represents the cultural identity that becomes income sources for Small and Mid-size enterprises (SMEs) entrepreneurs in Sabah. The sudden presence of the COVID-19 since March 2020 has impacted traditional food entrepreneurs. This research examines what strategies SMEs entrepreneurs are implementing. Factor Analysis is used to analyse 21 parameters of a new norm for the traditional food business. This study succeeded in developing three dimensions: enhancing existing business, new norm business and improving business skills. Entrepreneurs need to prepare strategies to meet new business norms. Support from the government and various agencies is required to enhance SME entrepreneurs' business capabilities.
\end{abstract}

Key Words; Traditional Food, SMEs, Covid-19, New norms

eISSN: 2398-4287@ 2021. The Authors. Published for AMER ABRA CE-Bs by e-International Publishing House, Ltd., UK. This is an open access article under the CC BYNC-ND license (http://creativecommons.org/licenses/by-nc-nd/4.0/). Peer-review under responsibility of AMER (Association of Malaysian Environment-Behaviour Researchers), ABRA (Association of Behavioural Researchers on Asians/Africans/Arabians) and CE-Bs (Centre for Environment-Behaviour Studies), Faculty of Architecture, Planning \& Surveying, Universiti Teknologi MARA, Malaysia.

DOI: https://doi.org/10.21834/ebpj.v6i16.2667

\subsection{Introduction}

Small and Medium Enterprises (SMEs) for the services and others sector can be defined through the annual income and the number of workers in each category: the micro, small and medium categories. The micro category's yearly income is less than RM 300,000 per annum, with a total number of workers of less than five. The annual income is from RM300, 000 to RM3 million ringgit per annum in the small category with less than 5 to 30 workers. Medium category can be defined with an annual income of RM3 million to RM20 million with a total workforce of between 30 to 75 workers. The definition of SMEs has been approved by the National SME Development Council (NSDC) in its 14th meeting in 2013 (SME Corp Malaysia, 2020). To date, the majority of traders in Malaysia are registered SMEs entrepreneurs and have contributed to the gross domestic product (GDP) was about 37 per cent in 2017, which forms the backbone of the national economy (Norazida, 2019).

The spread of Corona Virus Disease (Covid-19) resulted in the government issuing the Movement Control Order (MCO), which restricted the people's movement and closing its borders to tourists. The closure of SMEs premises on 18 March 2020 has brought about a massive impact on this sector, mostly on tourists purchasing their products. The Covid-19 crisis contributed to the cash flow problem among SMEs. In that respect, entrepreneurs had to find a new approach to regain the capital they have invested in their businesses. They also had to shift their business location by using the social media platform for all online transactions known as e-

eISSN: 2398-42870 2021. The Authors. Published for AMER ABRA cE-Bs by e-International Publishing House, Ltd., UK. This is an open access article under the CC BYNC-ND license (http://creativecommons.org/licenses/by-nc-nd/4.0/). Peer-review under responsibility of AMER (Association of Malaysian Environment-Behaviour Researchers), ABRA (Association of Behavioural Researchers on Asians/Africans/Arabians) and CE-Bs (Centre for Environment-Behaviour Studies), Faculty of Architecture, Planning \& Surveying, Universiti Teknologi MARA, Malaysia.

DOI: https://doi.org/10.21834/ebpj.v6i16.2667 
commerce or digital business (Chaffey et al., 2019). This scenario gradually attracted SMEs entrepreneurs facing the new norms in handling their business.

E-commerce has become quite significant to the Malaysian economy, especially for entrepreneurs to sustain their market share. This new norm of the business carried out by the SMEs entrepreneurs included using a digital business model, reorienting their product supply chain, and adapting their business according to consumer behaviour (Dennis et al., 2009). Online sales had become a competition among the SMEs entrepreneurs in marketing their products since enforcement of the Movement Control Order (MCO). Apart from that, e-commerce platforms such as Lazada and Shopee had enabled them to overcome the geographical constraints in delivering their goods to their customers during the pandemic. E-commerce marketing during the pandemic has proven to be a resilient method for entrepreneurs to be able to sustain vis-à-vis in practising the new norm.

With its multiple cultural and ethnic groups, Sabah is well-known in producing food products as one of its assets to domestic and international tourism. Dry food products such as kuih cincin, kuih lidah, amplang and wet food products such as binaya and pinasaakan are a hit among the locals and an attraction for tourists and traditional preparation which symbolises the cultural and ethnic diversity of Sabah. The effects of globalisation and technological development have succeeded in offering many entrepreneurs opportunities to use social media services such as Facebook, WhatsApp, and Instagram to open their market share. However, many entrepreneurs still rely on traditional methods, which are face-to-face transactions distributed in areas visited by tourists, such as the pasar tamu, restaurants, markets, and business premises. Entrepreneurs who conduct face-to-face sales are the most affected during the MCO. Even though digital usage in the new norm is encouraged among the SMEs, the entrepreneurs still face challenges such as lack of digital use skills, low creativity in online marketing, and no internet infrastructure (Amos and Rachel, 2020). According to Yakin et al. (2020), the commercialisation of traditional food product requires media coverage factors, tourists' hotspots and the cultural relationship with ethnic groups. This paper tends to identify how far the SMEs entrepreneurs in Sabah are willing to change their businesses' norms to ensure that traditional food products can still be a dominant force in the SMEs

\subsection{Literature Review}

\subsection{The Definition of Digital Marketing (E-commerce)}

In general, e-commerce can be understood as a platform that facilitates the selling and buying of products or services provided by entrepreneurs in cyberspace. Besides, e-commerce allows a customer to search and choose products in a catalogue. The payment process of e-commerce is done via credit or debit card and online banking transfer. E-commerce can be defined through four perspectives: first, communication perspective, through the dissemination of information and products electronically, secondly, a business perspective which is the application of technology into a more automated business. Third, the service perspective deals with the quality and fast delivery process. The fourth is the online perspective which refers to the purchase and sale of products between the trader and buyer (Chaffey et al., 2019).

\subsection{The New Norm of E-Commerce Marketing}

The marketing of SMEs products focuses more on the presence of tourists to obtain profits from their business. Rosnia Aznie et al. (2020) found that will increase a certain product's productivity if the number of tourists coming into the country increases, too. The method used by SMEs entrepreneurs to attract tourists and locals is by traditional trading (direct trade) at the location of tourists' spots, festive seasons and expositions or carnivals. Food can be a way to show the special features and characteristics of a country (Mitchell \& Hall, 2004); therefore, this industry can be a catalyst in helping to elevate the nation's economy. However, the traders were facing difficulties in marketing their products due to the decline of tourists. In maintaining viability and benefits in a business, the SMEs entrepreneurs need sources to successfully market their products, such as investors. These workers are skilled in product marketing and goods distribution (Norasiah and Mohd Nasir, 2007). These workers are skilled in product marketing and goods distribution (Norasiah and Mohd Nasir, 2007).

The digital transformation in businesses had been adopted for quite a while in marketing because it provided a better opportunity from the sales point of view and rebranding a product (Loonam et al., 2018). However, the spread of Covid-19 has impacted the entrepreneurs, which has caused competition in marketing the products digitally, i.e. e-commerce marketing. The President of the Malaysia SMEs Association announced that digital technology usage before this was only 10 to 20 per cent; however, after the MCO, marketing through digital technology, significantly, marketing via e-commerce, has increased to 40 per cent among the SMEs entrepreneurs (Hazwan Faisal, 2020). Those who were severely affected by the Covid-19 pandemic had optimised the digital technological edge in their products' marketing (Ziyadin et al., 2020). Not counting their geographical background, entrepreneurs could diversify their source of income despite facing physical constraints. In general, e-commerce sales have increased during the pandemic (Anam, 2020).

Nevertheless, not all entrepreneurs carried out their businesses digitally. Research done by the Canadian Emergency Response Benefits in Canada discovered that one out of four traders couldn't afford to operate their businesses online due to a lack of ICT knowledge and no understanding of converting their business operation to the online platform (Mabey, 2020). The implementation of e-commerce requires combining entrepreneurial skills and infrastructure such as machine, computer and high-speed internet (Williamson et al., 2003). Furthermore, it had not wholly ascertained the application of e-commerce in Malaysia due to various factors such as socio-economic, cultural and readiness factors (Nair et al., 2010). Entrepreneurial SMEs should understand consumers' 
behaviour towards the products of manufactured goods. Bakar and Jimel (2018) found that affective attitudes and altruism influence sustainable product acceptance.

Mohammad et al. (2020) believe that an adverse effect had emerged on the entrepreneurs who practised e-commerce. The presence of products from abroad that entered the Malaysian market will increase competition and decrease local products' demand. This matter will influence sales and buying behaviour among customers. Therefore, creative marketing in the behaviour business is imperative in attracting buyers' interest in cyberspace. Pictures of products uploaded on social media play an essential role in successful marketing.

\subsection{Methodology}

This research is undertaken to ascertain the new norm for traditional food business by SMEs entrepreneurs in Sabah. A total of 105 SMEs entrepreneurs were selected to become the respondents of this study using non-probability sampling. The questionnaire employs a Likert of 4 Scale 1(Strongly Disagree), 2(Disagree), 3(Agree), and 4(Strongly Agree). The quantitative approach is employed to develop a descriptive analysis that captures frequency values and mean score. Factor Analysis is used to analyse 25 parameters of a new norm for traditional food business by SMEs entrepreneurs. Factor analysis is a multivariate methodology to analyse the correlation between variables to analyse those grouped in the same category (Horst, 1965). As a result of factor analysis, only 21 variables are acceptable for further analysis. Mean analysis is undertaken to ascertain the new norm for traditional food business's dominant factor by SMEs Entrepreneurs. The relationship between the Likert scales was then interpreted using mean score analysis using the mean score propensity level used by Pepe and Fleming (1994) based on Table 1.

Table 1: Min score index

\begin{tabular}{ll}
\hline Min score index & Level \\
\hline 1.00 to 2.33 & Low $(\mathrm{L})$ \\
2.34 to 3.66 & Medium (M) \\
3.67 to 5.00 & High (H) \\
\hline
\end{tabular}

\subsection{Findings}

\subsection{SME Entrepreneurs Demography}

Table 2 briefly indicates the demography of the SMEs entrepreneurs in Kota Kinabalu. The majority of the entrepreneurs aged between 21 to 30 years old (30\%) followed with respondents aged 51 and above (23.3\%). The Brunei ethnic group dominates at 40 per cent, followed by those of the Bajau ethnic group (26.7\%). The respondents' most business duration is between 1-5 years (36.7\%) and 16 years and above $(23.3 \%)$.

Table 2: Respondent Demography

\begin{tabular}{ll}
\hline Age & Per cent $(\%)$ \\
\hline$<20$ years & 10 \\
$21-30$ years & 30 \\
$31-40$ years & 16.7 \\
$41-50$ years & 20 \\
51 years and above & 23.3 \\
\hline Race & Per cent $(\%)$ \\
Bajau & 26.6 \\
Brunei & 40 \\
Dusun & 6.7 \\
Kedayan & 10 \\
others & 16.7 \\
\hline Business Duration & Per cent (\%) \\
\hline $1-5$ years & 36.7 \\
6-10 years & 23.3 \\
$11-15$ years & 16.7 \\
16 years and above & 23.3 \\
\hline
\end{tabular}

\subsection{The Covid-19 Pandemic Impact on SME Marketing}

The spread of Covid-19 had caused the SMEs traditional food entrepreneurs to comply with a new norm in facing the unexpected effects in business. This matter had drastically influenced the marketing of their product (Harifah et al., 2020). Table 3 indicates the impact that SMEs traditional food entrepreneurs face. The most apparent effect is "difficult to secure new customers/buyers" (4.45 mean). The lack of buyers/customers causes this either from tourists or local buyers. Entrepreneurs choose to stick to the existing business in the new norm era as they are not confident with a new business/product ( 4.00 mean). They have to handle many 
processes that will only add to the workforce's difficulties and capital expenditure. Therefore, focusing on their existing business is the priority to them during this pandemic.

The new norm introduces entrepreneurs to e-commerce online product marketing. Some entrepreneurs did not get any expert guidance on e-commerce marketing (3.66 mean), most probably due to the lack of exposure or fees payment was imposed to attend the seminars and webinars. This state of affairs resulted in entrepreneurs who were not competent in marketing their products online, more efficiently (3.26 mean). Some entrepreneurs do not possess internet usage skills ( 3.05 mean), and some have no access to the internet (2.96 mean), causing them to face problems in marketing their products efficiently. Furthermore, internet usage requires some costs which are not affordable to the locals.

Table 3: New Norm Marketing Impact

\begin{tabular}{lll}
\hline Effect & Mean & Scale \\
\hline No knowledge of marketing method & 3.26 & Medium \\
No knowledge of the internet (online marketing) & 3.05 & Medium \\
Not confidence in trying a new business/product & 4.00 & High \\
No access to the internet to market products & 2.96 & Medium \\
No guidance from e-commerce marketing expert & 3.66 & High \\
Difficulty in getting new customers/buyers & 4.45 & High \\
\hline
\end{tabular}

\subsection{Strategy to Enhance Product Marketing}

SMEs entrepreneurs planned their strategies in facing the effects which emerged in marketing their products during this pandemic. The primary approach is to be creative in business (4.36 mean). The entrepreneurs use existing skills in drawing interest from customers by using the online advertisement. Meanwhile, adding entrepreneurship skill scored 4.03 mean. That is due to the entrepreneurs using youtube and google alternatives to improve their product marketing knowledge through online e-commerce. Increasing product quality (3.93 mean) is another SMEs entrepreneurs' strategy in increasing product marketing in this new norm. The recipe and its originality in taste can improve food product quality through the recipe and its originality in taste.

The next strategy is to attend a product marketing course through e-commerce (3.50 mean) either organised by the public or private sector. Findings from interviews carried out with respondents indicated that not all entrepreneurs could employ this strategy as there was an aspect of the participation fee. Only those chosen and fulfilled the criteria can attend the courses during this pandemic. Attending cooking classes (3.20 mean) was an initiative taken by the entrepreneurs who just started business since the MCO was enforced. The taking part of the cooking classes which were organised online with a nominal fee to assist new entrepreneurs. According to Fahrughazi et al. (2020), three factors enhancing the performance of online businesses in Malaysia, namely product abundance, product delivery and price of the product. It may influence the success of online businesses profit performance.

Table 4: Strategy of Increasing Market share in the New Norm

\begin{tabular}{lll}
\hline Strategy & Min & Scale \\
\hline Frequently attending e-commerce skills course & 3.50 & Medium \\
Increase product quality & 3.93 & High \\
Must be creative in business & 4.36 & High \\
Increasing entrepreneurship knowledge & 4.03 & High \\
Attend cooking class & 3.20 & Medium \\
\hline
\end{tabular}

\subsection{Factor Analysis of New Norm For Traditional Food Business by SMEs Entrepreneurs}

Factor analysis to construct factors on the readiness of entrepreneurs toward the new norm for traditional food business. The factor analysis is deemed appropriate if the value of $\mathrm{KMO}$ is bigger than 0.60 . It turned out that the value of $\mathrm{KMO}$ is 0.748 , which means that the data is free from problems relating to multicollinearity, and the items are suitable for factor analysis. The rest is significant where $p<0.05$ indicates that the correlation between the items is appropriate for factor analysis. Table 5 shows the KMO test results, Bartlett's Test, factors, the selected items, the loading factor, the eigenvalue, the variant, and Cronbach's Alpha.

Based on EFA results, the 'enhancing existing businesses' contributes 29.335 per cent with the eigenvalue of 7.267 .610 (see Table 2). This factor contains eight (8) items. The second important factor is 'new business norm '. The eigenvalue is 3.912 with the variant of 15.047 per cent. This factor also contains eight (8) item. Lastly, the third important factor is the 'improve business skills' factors with (5) items that contribute 7.519 per cent variant with the eigenvalue of 1.955 .

Table 5: Factors Analysis of New Norm For Traditional Food Business by SMEs Entrepreneurs

\begin{tabular}{llc}
\hline \multicolumn{1}{c}{ Item } & \multicolumn{2}{c}{ Factor } \\
\cline { 2 - 3 } & & \\
\hline Enhancing Existing Business & & \\
Maintaining existing business & 0.729 & \\
Self-delivery of food (COD) & 0.694 \\
Increase product quality & 0.677 & \\
Targeting local market & 0.652 \\
Diversifying sales product & 0.622 \\
On-demand sale & 0.619
\end{tabular}




\begin{tabular}{|c|c|c|c|}
\hline $\begin{array}{l}\text { Sell in bulk } \\
\text { Sending products to sundry shops }\end{array}$ & $\begin{array}{l}0.501 \\
0.591\end{array}$ & & \\
\hline \multicolumn{4}{|l|}{ New Norm Business - E-Commerce } \\
\hline $\begin{array}{l}\text { New marketing approach } \\
\text { Preparing computer/laptop to market product } \\
\text { Opening up market share through advertisement } \\
\text { Preparing internet access to market products } \\
\text { Orders through FB, Instagram and WhatsApp } \\
\text { Marketing products through e-commerce } \\
\text { Learning how to use the internet } \\
\text { Delivery through FoodPanda/GrabFood }\end{array}$ & & $\begin{array}{l}0.822 \\
0.792 \\
0.782 \\
0.777 \\
0.769 \\
0.677 \\
0.653 \\
0.621\end{array}$ & \\
\hline $\begin{array}{l}\text { Improving Business Skills } \\
\text { Increasing entrepreneurship knowledge } \\
\text { Creativity in business } \\
\text { Frequently attending courses } \\
\text { Increase product quality } \\
\text { Attending cooking classes }\end{array}$ & & & $\begin{array}{l}0.775 \\
0.724 \\
0.711 \\
0.677 \\
0.666\end{array}$ \\
\hline $\begin{array}{l}\text { Cronbach's Alpha } \\
\text { Total Variance Explained } \\
\text { Percentage Variance Explained }\end{array}$ & $\begin{array}{c}0.919 \\
7.627 \\
29.335\end{array}$ & $\begin{array}{c}0.847 \\
3.912 \\
15.047\end{array}$ & $\begin{array}{l}0.837 \\
1.955 \\
7.519\end{array}$ \\
\hline
\end{tabular}

Notes: Kaiser-Meyer-Olkin Measure of Sampling Adequacy $=0.748 ; X^{2}=921.90 ;$ Bartlett's Test of Sphericity Significance $=0.000 ; \mathrm{df}=325$

Factor analysis had constructed three factors: the first factor, 'enhancing existing businesses' second factor, 'new business norm', and 'improving business skills'. The mean value (Diagram 1) will list the dominant factors in entrepreneurs' readiness to enter new traditional food business norms.

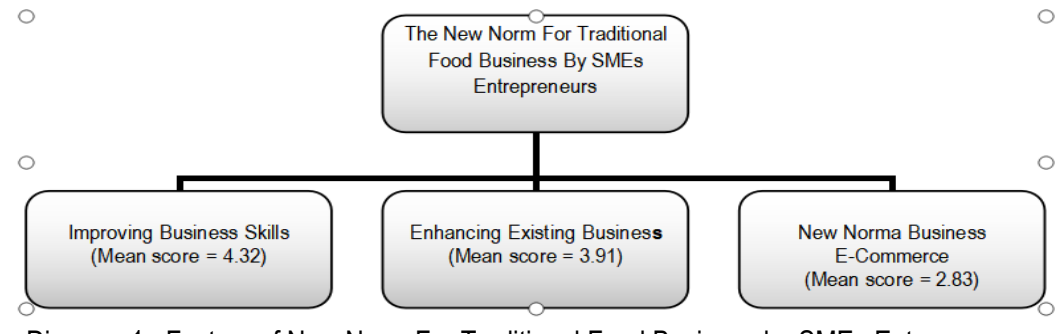

Table 6 shows the highest factor in the "improve business skills (mean 4.32), while the second-highest factor, "enhancing existing business" with the mean of 3.90 and the third factor is "new business norm" with a mean of 2.82. That shows that the entrepreneur is more willing to maintain the current business norm. Traditional food entrepreneurs, especially those in the micro size, require more time to equip themselves in the new norm, i.e. "e-commerce". They are not yet confident with the response towards marketing via ecommerce which they are to face (Mazzarol, 2015). That is mainly for those in rural areas facing difficulties in marketing their product due to poor internet coverage and badly affect their income. Expert guidance is highly required. Most entrepreneurs still lack knowledge of the legal aspect of excessive pricing in business to remain competitive in the industry (Abdullah \& Rosnan 2018). Findings from interviews with the respondents, participation in seminars and courses conducted by entrepreneurship experts require participation fees. Some SMEs entrepreneurs who can't afford those sessions obtain entrepreneurship knowledge through their own experience.

Table 6: Mean Score Of The New Norm For Traditional Food Business By SMEs Entrepreneurs

\begin{tabular}{|c|c|c|c|c|}
\hline & 1 : Enhancing Existing Business & Mean & Ave Mean & Level \\
\hline 1. & Maintaining existing business & 4.255 & \multirow{8}{*}{3.906} & \multirow{5}{*}{ Moderate } \\
\hline 2. & Self-delivery of food (COD) & 3.388 & & \\
\hline 3. & Increase product quality & 4.266 & & \\
\hline 4 & Targeting local market & 4.078 & & \\
\hline 5 & Diversifying sales product & 4.777 & & \\
\hline 6 & On-demand sale & 3.722 & & \\
\hline 7 & Sell in bulk & 3.966 & & \\
\hline 8 & Sending products to sundry shops & 2.795 & & \\
\hline \multicolumn{2}{|c|}{ Factor 2 : New Norm Business -E-Commerce } & & \multirow{8}{*}{2.825} & \multirow{8}{*}{ Moderate } \\
\hline 1. & Marketing through E-Commerce & 2.991 & & \\
\hline 2. & Use internet to market products & 2.444 & & \\
\hline 3. & Internet marketing (online marketing) & 2.344 & & \\
\hline 4 & Orders through FB, Instagram \& WhatsApp & 3.222 & & \\
\hline 5 & Opening up market through advertisement & 3.912 & & \\
\hline 6 & Access internet to market product & 2.444 & & \\
\hline 7 & Don't know how to use the internet & 2.344 & & \\
\hline
\end{tabular}




\begin{tabular}{|c|c|c|c|c|}
\hline 8 & Delivery through Foodpanda \& Grabfood & 2.901 & & \\
\hline \multicolumn{4}{|c|}{ Factor 3: Improving Business Skills } & \multirow{6}{*}{ Moderate } \\
\hline 1 & Increase knowledge of entrepreneurship & 4.422 & & \\
\hline 2 & Must be creative in business & 4.612 & & \\
\hline 3 & Sharpen skills & 4.734 & 4.322 & \\
\hline 4 & Frequently attending courses & 4.322 & & \\
\hline 5 & Attend cooking courses & 3.567 & & \\
\hline
\end{tabular}

\subsection{Discussion}

All this while, SMEs entrepreneurs conducted their business on a face-to-face basis or through appointed agents. During the MCO enforcement, the SMEs entrepreneurs faced a drastic drop in their source of income. Hence, the much-needed aid from the government such as PRIHATIN Economic Stimulus Package, PRIHATIN Special Grant, Wage Subsidy Program (PSU), and Moratorium I-Sinar KWSP and recently was Perlindungan Ekonomi \& Rakyat Malaysia (PERMAI). All assistance is to support business continuity and enhancing existing business. However, to sustain or increase their business on a long-term basis, entrepreneurs must improve their business skills and carry out a new marketing norm. Business can be maintained and enhanced if entrepreneurs use various alternatives for marketing their products such as online business, or better known as e-commerce. One strategy is to conduct business from home and market their products online. Despite this, the authorities regularly extended their help to the affected entrepreneurs to ensure they are not left out using digital technology to market their products. Digital usage in running a business has been utilised quite a while among some SMEs entrepreneurs to boost their income; however, this method has become a must and priority to the SMEs entrepreneurs since the MCO's enforcement to overcome their business cash flow problem.

Anyway, the entrepreneurs are resilient in handling the effect they are facing during this pandemic. Several government aids handed out to ease the burden they were facing. However, the new norm in business offered a new opportunity to the entrepreneurs to improve their skills and ability through their strategies (Siti Masayu and Fatimah, 2020). Online business demands visualization and pictures that are appealing to the customers visiting the entrepreneurs' websites. The use of the hashtag in each advertisement can also expedite the search for a product sold via e-commerce.

Consequently, the marketing product strategy via online will innovate the marketing of a product from packaging, distribution and promotion to increase clientele in the cyberspace. At once, that will increase the entrepreneurs' viability and offers them a higher chance of sustaining during the pandemic (Simon Larson and Simon Gustavsson, 2020). Therefore, the SMEs entrepreneurs' strategy to sustain during this pandemic demands the resilience and innovation in running their business and survive in the new business norm. What is of top priority is to increase more creative marketing which can generate maximum profits in their business.

\subsection{Conclusion}

In conclusion, this research has looked into the new norm in the business carried out by SMEs traditional food entrepreneurs during the pandemic. The new norm's impact can be observed when the SMEs traditional food entrepreneurs were compelled to market their products online (e-commerce). The main challenge for entrepreneurs is in securing new customers for their businesses. It isn't easy to convince their customers with products that are marketed through cyberspace for the first time. At once, this method dampens the efforts of the SMEs traditional food entrepreneurs who lack the skills in digital media in opening up their market share in e-commerce. The new norm also contributed to the entrepreneurs geographically relocating their business to areas within their homes vicinity during the MCO enforcement. Nevertheless, the entrepreneurs streamlined their strategies to shield their products creatively and improve their entrepreneurship knowledge to be viable. Therefore, the strategy practised by SME entrepreneurs to stay in business throughout this pandemic needs to have resilience and innovation in their business to weather the new business norms.

The results provide an initial overview of SME entrepreneurs' willingness to comply with new norms to pursue their traditional food business. Even the government provides various forms of assistance; the long-term strategy needs to start at the earliest possible time. SME entrepreneurs need more advanced knowledge relating to e-commerce to commercialise their products more effectively. The finding can be used as measurement factors for SME entrepreneurs to plan the way to market their product efficiently through technology.

\section{Acknowledgement}

The writers would like to extend their gratitude to Universiti Malaysia Sabah to endow the financial research grant under the Special COVID-19 Fund (SDK 0302-2020), which has made this research possible. Thank you for the permission to use the findings of this research to be shared in this publication.

\section{References}

Abdullah, N. C., \& Rosnan, H. (2018). Excessive Pricing by SMEs: A Comparative Approach of Legislators' Behaviour and Sellers' Behaviour. Environment-Behaviour Proceedings Journal, 3(8), 109-114. 
Ambad, S. N. A., Andrew, J. V., \& Amit, D. H. D. A. (2020). Growth Challenges of SMEs: Empirical Evidence in Sabah, Malaysia. ASEAN Entrepreneurship Journal, 6(1), 8-14.

Amos Tong dan Rachel Gong. (2020). The Impact of Covid-19 on SME Digitalisation in Malaysia. Research Centre of the London School of Economics and Political Science (LSE).

Anam. B, Hamza. A, Hafiz. M.B, dan Ahmed. U.K. (2020). E-commerce Trends During Covid-19 Pandemic. International Journal Of Future Generation Communication and Networking. Vol.13, No.2, 2020 pp.1449-1452

Bakar, M. F. A., \& Anak Jimel, C. (2020). Attitude towards Sustainable Product among Malaysian Consumers. Environment-Behaviour Proceedings Journal, 5(SI3), 3-9.

Chaffey, D., Edmundson-Bird, D., \& Hemphill, T. (2019). Digital business and e-commerce management. Pearson UK.

Dennis, C., Merrilees, B., Jayawardhena, C., \& Wright, L. T. (2009). E-consumer behaviour. European journal of Marketing.

Fahrughazi, S. F. M., Hashim, M. R., \& Kamaluddin, A. (2020). Factors Enhancing Performance of Online Businesses in Malaysia. Environment-Behaviour Proceedings Journal, 5(15), 1-4.

Harifah Mohd Noor, Jabil Mapjabil, Adilah Md Ramli, Jurry Foo, Ubong Imang dan Rima Abdul Rahman. (2020). Resilien Keusahawanan Makanan Tradisi Sebagai Produk Pelancongan dalamTempoh Perintah Kawalan Pergerakan (PKP) Sepanjangan Pandemik Covid-19 di Negeri Sabah. Jorunal of Islamic , Social, Economics, and Development (JISED). Volume: 5 issues: 32 (October, 2020) pp.50-62

Hazwan Faisal, M. (2020). Pelan pemulihan bantu PKS, usahawan bertahan. Berita Harian.

Loonam, J., Eaves, S., Kumar, V., \& Parry, G. (2018). Towards digital transformation: Lessons learned from traditional organizations. Strategic Change, 27(2), 101-109.

Mabey, T. (2020). How COVID-19 Affects Rural Business. Retrieved on 26 th January 21 from Ignite. https://igniteatlantic.com/2020/04/22/how-COVID-19-affectsrural-business/.

Mazzarol, T. (2015). SMEs engagement with e-commerce, e-business and e-marketing. Small enterprise research, 22(1), 79-90.

Mohammad. W.H, Farzana. A.S, Ashiqul. H, Mashrekha. A. (2020). The Impact of Coronavirus (Covid-19) on Business in Malaysia. Asian Journal of Multidisciplinary Studies. Vol. 3, No. 1.

Nair, M., Han, G., Lee, H., Goon, P., \& Muda, R. (2010). Determinants of the digital divide in rural communities of a developing country: The case of Malaysia. Development and Society, 39.

Norazida Ibrahim. (2019). Sumbangan Perusahaan Kecil dan Sederhana (PKS) Masyarakat Melayu: Kajian Kes di Malaysia. Universiti Malaya. 1-11.

Noorasiah Sulaiman dan Mohd Nasir Mohd Saukani. (2007). Modal Sosial dalam Mempertingkat Daya Saing Firma Perusahaan Kecil dan Sederhana (PKS). IJMS 14 (2), 93-111 (2007)

Rosniza. A. C. H, Nur Ayuni, M.H dan Rozmiza, M. Z. (2018). Impak sektor Pelancongan Terhadap Perkembangan Perusahaan Kecil dan Sederhana (PKS) di Cherating, Pahang. Geografi Vol. (6), No. (3) Special Issue, (2018), 35-43. Penerbit Universiti Pendidikan Sultan Idris 2018

Pepe, M. S., Reilly, M., \& Fleming, T. R. (1994). Auxiliary outcome data and the mean score method. Journal of Statistical Planning and Inference, 42(1-2), 137-160 Simon Larsson dan Simon Gustavsson. (2020). Marketing Innovation for SMEs during Covid-19 Pandemic. Lulea University of Technology. 1-80

SME.Corp Malaysia. (2020). Definition of SMEs. Accessed from https://www.smecorp.gov.my/index.php/my/polisi/2020-02-11-08-01-24/sme-definition on 16 January 2021.

Siti Masayu Rosliah Abdul Rashid dan Fatimah Hassan. (2020). Amalan dan Penglibatan Peniaga Kecil melalui Perniagaan Digital Semasa Pandemik Covid-19 di Malaysia. Geografi Vol.8(2), 1-20. Doi.org/10.37134/geografi.vol8.2.1.2020.

Yakin, H. S. M., Moi, C. T., Totu, A., Sintang, S., Houi, Y. O. B., \& Lukin, S. A. (2020). Impak Modenisasi dan Pengkomersilan Terhadap Keaslian Makanan Tradisi dan Identiti Budaya Etnik Kadazan-Dusun di Sabah. Borneo International Journal eISSN 2636-9826, 2(4), 37-46.

Williamson, I. O., Lepak, D. P., \& King, J. (2003). The effect of company recruitment web site orientation on individuals' perceptions of organizational attractiveness. Journal of Vocational Behavior, 63(2), 242-263.

Ziyadin, S., Suieubayeva, S., \& Utegenova, A. (2019). Digital transformation in business. In International Scientific Conference "Digital Transformation of the Economy: Challenges, Trends, New Opportunities" (pp. 408-415). Springer, Cham. 